\title{
Ernest Hemingway's short story Cat in the rain (1925): A prototype of narrative and emotion
}

\section{Krzysztof Kosecki}

University of Łódź, Poland

\begin{abstract}
Ernest Hemingway's (1899-1961) short story "Cat in the rain" (1925/1953) describes the weakening of emotional bond between an American couple living in Italy and the gradual emergence of romantic affection between the wife and the keeper of the hotel in which they are staying. Adopting the perspectives of Cognitive Poetics (Gavins \& Steen, 2003; Lakoff \& Turner, 1989; Stockwell, 2002; Turner, 1991, 1996) and narratology (Hogan, 2003, 2011), the analysis makes two claims: 1. Hemingway's narrative reflects a prototypical pattern of the literary plot of its genre. 2. Metaphors and metonymies functioning in the structure of the narrative represent various aspects of a prototypical scenario of romantic love. Both elements make the short story convincing in spite of its condensed form.
\end{abstract}

Key words: emotion, metaphor, metonymy, narrative, prototype, romantic love.

\section{Introduction}

Narratives usually mean more than sequences of events that make them up. Ernest Hemingway's (1899-1961) short story "Cat in the rain" (1925/1953) concisely describes the weakening of relationship between an American couple living in a hotel in Italy and the gradual emergence of emotional bond between the wife and the Italian hotel-keeper. Though only a few pages long, the narrative owes much of its condensed effect to Hemingway's skilful blending of a prototypical narrative structure with an equally prototypical representation of various stages of romantic love by means of novel uses of conventional conceptual metaphors and metonymies. 


\section{Methodology: Prototypes, narratives, and emotions}

Contemporary cognitive linguistics claims that conceptual categories involve prototypical elements in their centres and some fuzziness at their boundaries (Rosch, 1975; Lakoff, 1987, 12-57). As a result, some of the members are judged as more representative than other members. Thus, for example, for most people CHAIR is a more prototypical element of the category FURNITURE than CARPET or TABLE LAMP (Evans \& Green, 2006, p. 254).

Cognitive Poetics applies such principles of categorization to the analysis of literary texts. It assumes that literary genres, narratives, and characters can also be typical and atypical (Lakoff \& Turner, 1989; Stockwell, 2002; Gavins \& Steen, 2003; Gibbs, 2003). Because narratives communicate universal ideas, emotions, and values, their effect to a large extent depends on prototypicality of their structures and contents.

Narratology, in turn, is mainly concerned with shared elements of narrative patterns of individual literary genres. Its beginnings go back to Vladimir Propp's (1928/1968) analyses of Russian folk tales within the formalist tradition (Jameson, 1972, pp. 64-69). Narratologists generally focus on

the way that narrative discourse fashions a story-the mere sequence of events in time-into the organized and meaningful structure of a literary plot. ... The general undertaking is to determine the rules, or codes of composition, that are manifested by the diverse forms of plot, and also to formulate the "grammar" of narrative in terms of structures and narrative formulae that recur in many stories, whatever the differences in the narrated subject matters. (Abrams, 1999, p. 173)

Joseph Campbell's (1949) theory of mono-myth and Tzvetan Todorov's (1969) description of the "grammar" Boccaccio's (1313-1375) Decameron (1353) are well-known analyses that revealed common meaningful patterns in literary works. More recently, Patrick Colm Hogan $(2003,2011)$ employed cognitive and narratological criteria in the description of narrative patterns of stories that reflect prototypical emotions. Such narratives often depend for their form and subject matter on novel uses of conventional metaphors and metonymies (Crisp, 2003, pp. 99-113; Kövecses, 2002, pp. 43-55; Lakoff \& Turner, 1989, pp. xi-xii, 101; Stockwell, 2003, pp. 105-119). 


\section{Prototypical narratives}

A prototypical short story aims at achieving what Edgar Allan Poe (1809-1849), reviewing Nathaniel Hawthorne's (1804-1864) tales, called "a certain unique and single effect" (1842/1986, p. 589 cit. in Abrams, 1999, p. 286). Its narrative involves five elements. The realistic setting introduces the location and the time of the events. Weather can be a part of the setting that provides clues to the general mood of the characters. The exposition contains information about the characters usually before they begin to change in the course of the events. In the complication some dramatic event occurs and a problem emerges out of the situation of the characters. The complication leads to the climax, which often involves some conflict between the characters. In the resolution the conflict is decided and the expectations of the characters may be confirmed or denied (Abrams, 1999, pp. 224-228; Cassill, 1978, pp. xvii-xix, 689-695). The narrative usually begins close to a climax (Abrams, 1999, p. 286) and follows the time line without any flashbacks. The number of characters is limited and they are not developed in detail. Some balance between the focus on the characters and the external action (Abrams, 1999, p. 286) also contributes to the prototypicality of the narrative. Finally, many short stories involve a metonymic relation of the PART FOR WHOLE type between a single word and their theme (Cassill, 1978, p. xxiv), which emphasizes their message. ${ }^{1}$ The "recognition that stories are at the heart of cognitive understanding" (Stockwell, 2002, p. 124) means that prototypical narratives are likely to produce the most convincing effects.

Hemingway's narrative has all prototypical elements of its genre. ${ }^{2}$ It begins in the realistic setting of a hotel somewhere in Italy, whose room faces the sea, the public garden, and the war monument located in the square. People come to the monument, so the memory of World War I is still fresh. It is also raining outside. The war and the rainy weather both serve as clues to the moods of the two characters, whose marriage is going through a crisis. ${ }^{3}$ The exposition introduces the characters and the relation between them. In the hotel room, George - the

${ }^{1}$ William Wordsworth's (1770-1850) poem "I wandered lonely as a cloud" (1807/1975), though an example of a different genre, well illustrates this element: the word "dance" appears in all four stanzas and emphasizes the harmony of the narrator's experience with the universe.

2 The same pattern is present in the short story "The end of something" (1925/1953), which represents the break-up between a couple of young Americans living in mid-West. Hemingway's other stories are different. For example, "Snows of Kilimanjaro" (1936/1953) and "The Short Happy Life of Francis Macomber" (1936/1953) have much more complex structures that involve many flashbacks.

3 The war forms the background for an unhappy relationship also in the short story "Mr. and Mrs. Elliot" (1925/1053). 
husband - is engrossed in reading. He neither takes interest in his wife nor in what is going on outside. The nameless wife is bored - she is looking out of the window into the garden in the rain. No flashbacks provide information about the reasons for the situation. The complication begins when the wife notices a little cat trying to find shelter from the rain under one of the tables. The plot takes a dramatic turn when she says that wants to have it very much. She decides to go downstairs and bring the kitty into the room. Though the husband offers to help her, she wants to go alone. On her way, she is greeted by the Italian hotel-keeper, whom she likes. The narrative reaches the climax when the wife goes out of the building and a maid with an umbrella goes out to protect her from the rain - she explains that the hotel-keeper has sent her. The wife does not find the cat and goes back upstairs sad and disappointed. The conflict is resolved when the wife asks her husband if she should grow her hair out, says that she wants a bun at the back of her neck, and a cat to stroke, a table with her own silver, and some new clothes. He is not interested and tells her to shut up and read a book instead. Just then the maid knocks on the door - at the request of the hotel-keeper she has brought another cat for the wife (Cat in the rain. Summary, 2018).

\section{Prototypical emotions}

Hogan (2003) argues that there are prototypical narrative patterns underlying stories that represent prototypical emotions. Basing on the cognitive concept of a 'frame' understood as "a structured mental representation of a conceptual category" (Kövecses, 2006, p. 64), he analyses narratives of emotions as telic structures that involve agents, their goals, and causal sequences of events.

Happiness is a prototypical emotion. One of its forms involves romantic love, which leads to the union of two persons that culminates in their happiness (Kövecses, 2006, pp. 88-89). Its prototypical scenario or frame is as follows:

sexual attraction $\rightarrow$ romantic love $\rightarrow$ romantic union (marriage) $\rightarrow$ enduring happiness (Kövecses, 2006, p. 91; Hogan, 2011, pp. 90-91)

Love understood as a union thus presupposes physical closeness and spending a lot of time together (Kövecses, 1986, pp. 64-65). People in a romantic relationship not only want to be together, but the unity also involves "perfect harmony, idyllic state" (Kövecses, 1986, p. 63). two obvious symptoms of disintegration of the union are the increase of spatial distance and the decrease of communication between the lovers. 
Hemingway's narrative sets out at the stage when the romantic union between the American couple begins to crumble. First, though the husband and the wife are staying in one place, they are physically separated. The increase of the spatial distance between the spouses means that they no longer function as a unit. The husband is also immersed in reading and inward-looking; the wife takes interest in the outside world looking out onto the square and wanting to have the little kitty when she notices it. They live in two different worlds between which there is little communication.

At the same time, attraction between the American wife and the Italian hotelkeeper gradually develops:

The wife went downstairs and the hotel owner stood up and bowed to her as she passed the office. ... He was an old man and very tall... He stood behind his desk in the far end of the dim room. The wife liked him. She liked the deadly serious way he received any complaints. She liked his dignity. She liked the way he wanted to serve her. She liked the way he felt about being a hotel-keeper. She liked his old, heavy face and big hands. (Hemingway, 1925/1953, p. 168)

A form of beauty, which goes beyond the physical aspects and involves such characteristics as personality and way of being, has effect on the wife. The liking is still passive - she experiences it, but she is not affected to the point of losing control $^{4}$ (Kövecses, 1986, pp. 68-70).

The wife's being attracted to the hotel-keeper is an early stage of the scenario of a prototypical romantic relationship. First, he maintains eye contact with her in the part of the corridor where the office is. Secondly, as she is about to go out into the rain to find the cat, the keeper sends a maid with an umbrella to protect her from the rain. He thus wants to take care of the wife. When the wife returns to her room disappointed, he bows to her again:

Something felt very small and tight inside the girl. The padrone made her feel very small and at the same time really important. She had a momentary feeling of being of supreme importance. (Hemingway, 1925/1953, p. 169)

Finally, having noticed that the wife did not find the kitty, he sends a different cat to please her:

In the doorway stood the maid. She held a big tortoise-shell cat pressed tight against her and swung down against her body. "Excuse me," she said, "the padrone asked me to bring this for the Signora." (Hemingway, 1925/1953, p. 170)

\footnotetext{
${ }^{4}$ A stronger emotion, including sexual desire, may be mediated by liking (Kövecses, 1986, p. 70).
} 
The gift is a token of care and affection of the hotel-keeper for the wife. Four major elements of a prototypical romantic relationship - liking on the side of the wife and eye contact, care, and a gift on the side of the manager - are thus present.

\section{Narratives and emotions: Metaphors and metonymies}

LOVE IS A UNITY OF COMPLEMENTARY PARTS, motivated by the experience of physical closeness, is a major metaphor structuring the concept of romantic union. Some linguistic examples of its use are: We were made for each other; We are one; Theirs is a perfect match; She has an attachment to him (Kövecses, 1986, pp. 6263). In narrative structures, the source domain of the metaphor takes the form of elements of the setting and the characters' actions. In Hemingway's short story, the American spouses are gradually drifting apart emotionally, so the spatial distance between them increases: the husband lies on the bed; the wife stands at the window. As affection between the wife and the Italian hotel-keeper gradually develops, the distance between them shrinks. At first, he is at the far end of the room, but on two occasions he attempts to get closer to her: first, he asks the maid to bring the umbrella for the wife who goes out into the rain; second, he sends a different, much bigger cat, directly to the room that she and her husband occupy.

EMOTIONS ARE PHYSICAL FORCES is another metaphor in the structure to the narrative. Rooted in Talmy's (1988) force dynamics model of language based on the concepts of forces and barriers (Sweetser, 1999, pp. 51-54), the metaphor is motivated by the primary experience of "achieving results by exerting forces on physical objects to move or change them" (Lakoff \& Johnson, 1999, p. 53). It underlies the following expressions: That was a terrible blow; Her whole life revolves around him; I am attracted to her; I was magnetically drawn to her. They represent various emotions as physical, gravitational, or magnetic forces respectively (Kövecses, 2006, p. 218). The metaphor is present in actions undertaken by the characters. The American wife, feeing bored and lacking affection, is drawn to the kitty sitting under the table. She finds the hotel-keeper attractive. He also seems to be attracted to her because he provides the umbrella and later sends another cat for her to relieve the disappointment when she does not find the kitty. Though no words in the text reflect the metaphor, its non-linguistic realization is in the events that make a sub-part of the narrative.

The cat has a pivotal function in the narrative. It represents the emotional state of the wife, who feels lonely with her husband and seeks some affection; at the end of the story, it is an expression of the hotel-keeper's care for her. The 
animal - be it the kitty or the big cat that the hotel-keeper sends - functions as the vehicle of the metonymy THE OBJECT FOR THE EMOTION. As the narrative is linear, the selection of the cat as the focus of the story, as well as its simultaneous use as the meeting point of the emotions of boredom and affection produces what Victor Shklovsky (1917/1965) called the artistic effect of "defamiliarization" - the conventional emotions and conflicts are represented in a novel way.

Proper names also play a role in the narrative. In contrast to common appellatives, "their semantic function lies in the naming and identifying of individuals" (Jäkel, 1999, p. 211). Unlike her husband George, the wife has no name. Its lack has a twofold function: first, she acts as a "slot" that can be filled with meaning and so represents any other woman in a similar situation; secondly, and more importantly in the context, it implies that the wife remains in the background and is unimportant. ${ }^{5}$ Hemingway's negated use of the common metonymy THE NAME FOR THE PERSON ${ }^{6}$ thus represents the insignificant position of the wife.

Finally, the word that servers as a clue to the theme and meaning of the story is cat. Mentioned in its title, it also has the structuring function related to emotions. However, the word she appears more frequently than is justified by its function as an anaphoric pronoun referring to the wife. Its repeated occurrence indicates that also the American wife is the focal point of the story and that - because she has no name - she is insignificant.

\section{Conclusions}

Literary texts owe their artistic effect both to structure and contents. Combination of highly salient features on both these levels usually augments the effect. "Cat in the rain" employs all prototypical features of the structure of a short story to represent the prototypical romantic union. At the same time, like so many other Hemingway's stories, it is a compact narrative in realistic setting, written in simple, direct style with little descriptive detail (Anderson, 1994, p. 109; Levin, 1965, p. 107). That is why the condensed story is so convincing.

${ }^{5}$ For a contrast, the characters of "Mr. and Mrs. Elliot" (1925/1953) have common names so that they can be regarded as prototypes of their category.

${ }^{6}$ The negated use of the metonymy should be understood as "no name = no person". 


\section{References}

Abrams, M. H. (1999). A Glossary of Literary Terms. Boston: Heinle.

Anderson, C. R. (1994). Hemingway's other style. In G. Monteiro (ed.), Critical Essays on Ernest Hemingway's "A Farewell to Arms", (pp. 109-116). New York: Hall.

Campbell, J. (1949). The Hero with a Thousand Faces. Princeton, NJ: Princeton University Press.

Cassill, R. V. (1978). Talking about fiction. In R. V. Cassill (ed.), The Norton Anthology of Short Fiction: Shorter Edition, (pp. xvii-xxviii). New York: Norton.

Crisp, P. (2003). Conceptual metaphor and its expressions. In J. Gavins \& G. Steen (eds.), Cognitive Poetics in Practice, (pp. 99-113). London: Routledge.

Evans, V. \& Green, M. (2006). Cognitive Linguistics: An Introduction. Edinburgh, UK: Edinburgh University Press.

Gavins, J. \& Steen, G. (eds.). (2003). Cognitive Poetics in Practice. London: Routledge.

Gibbs, R. W. (2003). Prototypes in dynamic meaning construal. In J. Gavins \& G. Steen (eds.), Cognitive Poetics in Practice, (pp. 27-40). London: Routledge.

Hemingway, E. (1953). Cat in the rain. In The Short Stories of Ernest Hemingway, (pp. 167-170). New York: Scribner. (Original work published 1925).

Hemingway, E. (1953). A clean, well-lighted place. In The Short Stories of Ernest Hemingway, (pp. 379-383). New York: Scribner. (Original work published 1936).

Hemingway, E. (1953). The short happy life of Francis Macomber. In The Short Stories of Ernest Hemingway, (3-37). New York: Scribner. (Original work published 1936).

Hemingway, E. (1953). Snows of Kilimanjaro. In The Short Stories of Ernest Hemingway, (pp. 52-77). New York: Scribner. (Original work published 1936).

Hemingway, E. (2003). The end of something. In The Short Stories of Ernest Hemingway, (pp. 107-111). New York: Scribner. (Original work published 1925).

Hemingway, E. (2003). Mr. and Mrs. Elliot. In The Short stories of Ernest Hemingway, (pp. 161-164). New York: Scribner. (Original work published 1925).

Hogan, P. C. (2003). The Mind and Its Stories: Narrative Universals and Human Emotion. Cambridge, UK: Cambridge University Press.

Hogan, P. C. (2011). What Literature Teaches Us About Emotion. Cambridge, UK: Cambridge University Press.

Jäkel, O. (1999). Metonymy in onomastics. In K.-U. Panther \& G. Radden (eds.), Metonymy in Language and Thought, (pp. 211-228). Amsterdam: Benjamins.

Jameson, F. (1972). The Prison-House of Language: A Critical Account of Structuralism and Russian Formalism. Princeton, NJ: Princeton University Press.

Kövecses, Z. (1986). Metaphors of Anger, Pride, and Love: A Lexical Approach to the Structure of Concepts. Amsterdam: Benjamins.

Kövecses, Z. (2002). Metaphor: A Practical Introduction. Oxford, UK: Oxford University Press.

Kövecses, Z. (2006). Language, Mind, and Culture: A Practical Introduction. Oxford, UK: Oxford University Press.

Lakoff, G. (1987). Women, Fire, and Dangerous Things: What Categories Reveal About the

Mind. Chicago: University of Chicago Press.

Lakoff, G., \& Johnson, M. (1999). Philosophy in the Flesh: The Embodied Mind and Its Challenge to Western Thought. New York: Basic.

Lakoff, G., \& Turner, M. (1989). More Than Cool Reason: A Field Guide to Poetic Metaphor. Chicago: Chicago University Press. 
Levin, H. (1965). Observations on the style of Ernest Hemingway. In C. Baker (ed.), Hemingway and His Critics: An International Anthology, (pp. 93-115). New York: Hill Wang.

Poe, E. A. (1986). Reviews of Hawthorne's Twice-Told Tales. In N. Baym et al. (eds.), The Norton Anthology of American Literature: Second Edition Shorter, (pp. 585-593). New York: Norton. (Original work published 1842).

Propp, V. (1968). The Morphology of the Folktale (L. Scott, Trans.). Austin, TX: University of Texas Press. (Original work published 1928).

Rosch, E. (1975). Cognitive representations of semantic categories. Journal of Cognitive Psychology: General, 104, 192-233.

Shklovsky, V. (1965). Art as technique. In L. T. Lemon \& M. J. Reis (eds. and trans.), Russian Formalist Criticism: Four Essays, (pp. 3-24). Lincoln, NE: University of Nebraska Press. (Original work published 1917).

SparkNotes LLC. 2018. Cat in the rain. Summary. At http://www.sparknotes.com > ... > Literature Study Guides > In Our Time. Accessed 6 March 2018.

Stockwell, P. (2002). Cognitive Poetics: An Introduction. London: Routledge.

Sweetser, E. E. (1990). From Etymology to Pragmatics: Metaphorical and Cultural Aspects of Semantic Structure. Cambridge, UK: Cambridge University Press.

Talmy, L. (1988). Force dynamics in language and cognition. Cognitive Science, 12, 49-100.

Todorov, T. (1969). Grammaire du Décaméron [The Grammar of Decameron]. The Hague, The Netherlands: Mouton.

Turner, M. (1991). Reading Minds: The Study of English in the Age of Cognitive Science. Princeton, NJ: Princeton University Press.

Turner, M. (1996). The Literary Mind. New York: Oxford University Press.

Wordsworth, W. (1975). I wandered lonely as a cloud. In M. H. Abrams (ed.), The Norton Anthology of English Literature: Major Authors Edition, (p. 1427). New York: Norton. (Original work published 1807). 